\title{
PENGARUH AKUPRESUR TERHADAP PENINGKATAN KEKUATAN OTOT DAN ACTIVITIES OF DAILY LIVING (ADL) PADA PASIEN STROKE NON HEMORAGIK DI UNIT STROKE RSUD A. WAHAB SJAHRANIE SAMARINDA
}

\author{
Ns. Theresia Tutik Ismiati, M.Kep', Maria Astrid M.Kep.,Ns.,Sp.KMB, Dr. Ir. Wilhelmus Hary \\ S.,MM.,IAI, Risma Yuniarlina RS, SKp., MS.
}

Jurusan Keperawatan, STIKES Dirgahayu Samarinda

Jl. Pasundan Nomor 21 Kelurahan Jawa Kecamatan Samarinda Ulu

Kota Samarinda Kalimantan Timur Kode Pos 75122

email: theresialegowo88@gmail.com

\begin{abstract}
Abstrak
Stroke merupakan penyakit yang disebabkan adanya gangguan suplai darah keotak. WHO (World Health Organization) menyampaikan 15 juta orang menderita stroke di seluruh dunia setiap tahun. Sebanyak 5 juta orang mengalami kematian dan 5 juta orang mengalami kecacatan yang menetap. Yayasan Stroke Indonesia (Yastroki) mencatat bahwa Indonesia menduduki urutan pertama di Asia dengan penderita stroke terbanyak dan menjadi penyakit penyebab kematian tertinggi di Indonesia. Stroke berdampak pada disfungsi ekstremitas berupa penurunan kekuatan otot yang akan berdampak pada penurunan kemampuan Activities of daily living (ADL). Terdapat beberapa terapi yang telah dilakukan untuk mengatasi kelemahan otot dan keterbatasan ADL seperti latihan rentanggerak, pemberian posisi, dan akupresur yang merupakan salah satu bentuk terapi yang dapat dilakukan untuk mengembalikan fungsi ekstremitas. Penelitian ini bertujuan mengetahui pengaruh intervensi akupresur terhadap kekuatan otot ekstremitas dan Activities Of Daily Living (ADL) pada Pasien Stroke. Penelitian ini merupakan penelitian kuantitatif menggunakan metode kuasi eksperimen pre-post test design melibatkan 113 responden kedalam 2 kelompok yaitu kelompok intervensi 88 responden dan kelompok kontrol 25 responden. Hasil penelitian didapatkan responden laki-laki $(51,3 \%)$, usia 45-59 tahun $(58,4 \%)$, dan mengalami serangan pertama (85\%). Setelah intervensi 7 hari pada masing-masing responden, didapatkan perbedaan yang signifikan peningkatan kekuatanotot dan ADL sebelum dengan sesudah intervensi: kekuatan otot ekstremitas kanan $(\mathrm{p}=0,000)$; kekuatan ekstremitas kiri $(\mathrm{p}=0.000)$; dan ADL $(\mathrm{p}=0.000)$. Karakteristik responden yang berpengaruh terhadap kekuatan otot dan ADL adalah usia dan frekuensi stroke $(\mathrm{p}<0.05)$, sedangkan tidak ada pengaruh jenis kelamin ( $p>0.05$ ). Simpulan penelitian ini bahwa akupresur merupakan terapi yang efektif terhadap peningkatan kekuatan otot dan ADL pasien stroke. Penelitian ini merekomendasi akupresur sebagai terapi komplementer untuk meningkatkan kekuatan otot dan ADL pasien stroke.
\end{abstract}

Kata kunci: akupresur, kekuatanotot, Activities of daily living (ADL)

\section{Abstract}

Stroke is a disease caused by the interruption of blood supply to the brain. WHO (World Health Organization) stated 15 million people world wide suffer a stroke each year. As many as 5 million people are death sand 5 million people have permanent disability. Stroke Foundation of Indonesia (Yastroki) noted that Indonesia ranks first in Asia with the majority of stroke patients and become leading causes of death in Indonesia. Stroke affects extremity dysfunction such decreased muscle strength which will contribute to the decline ability of Activities of daily living $(A D L)$. There are several the rapies that have been done to over come muscle weakness and limitations of the ADL such as range of movement exercises, positioning, and acupressure is one form of therapy that can be done to restore extremity function. This study aims to determine the effect of acupressure intervention on limb muscle strength and Activities Of Daily Living (ADL) In Stroke Patients. Quantitative Study of quasi-experiment pre-post test design involved 113 respondents into two groups: the intervention group with 88 respondents and the control group with 25 respondents.The result showed male respondents (51.3\%), aged 45-59 years (58.4\%), and the first attack (85\%). After the intervention of 7 day sine ach ofthe respondents, found significant differences increase muscle strength and $A D L$ before the after intervention: right limbmuscle $\operatorname{strength}(p=0.000)$; left limbstrength $(p=0.000)$; and ADL $(p=0.000)$. Respondent characteristics that influence muscle strength and $A D L$ were age and frequency of stroke $(P<0.05)$, where as no influence of gender ( $p>0.05)$. The conclusions of this study that acupressureis an effective therapy on increase muscle strength and ADL of stroke patients. This research recommended acupressure as a complementary therapy to improve muscle strength andADLof stroke patients. 


\section{PENDAHULUAN}

Stroke adalah istilah yang digunakan untuk menggambarkan perubahan neurologis yang disebabkan oleh adanya gangguan suplai darah ke bagian dari otak. Dua jenis stroke yang utama adalah iskemik dan hemoragik.

Stroke iskemik disebabkan oleh adanya penyumbatan akibat gumpalan aliran darah baik itu sumbatan karena thrombosis (penggumpalan darah yang menyebabkan sumbatan di pembuluh darah) atau embolik (pecahan gumpalan darah/udara/benda asing yang berada dalam pembuluh darah sehingga dapat menyumbat pembuluh darah otak).

Data statistik dunia WHO (World Health Organization) menunjukkan 15 juta orang menderita stroke diseluruh dunia setiap tahun. Sebanyak 5 juta orang mengalami kematian dan 5 juta orang mengalami kecacatan yang menetap (WHO, 2011). Di Amerika Serikat sekitar 550.000 orang mengalami stroke dan menjadi penyebab sekitar 150.000 kematian setiap tahunnya. Ketika stroke yang kedua kalinya dimasukkan dalam kondisi tersebut, angka kejadian tersebut meningkat menjadi 700.000 per tahun hanya untuk di Amerika Serikat sendiri. Yayasan Stroke Indonesia (Yastroki) mencatat bahwa Indonesia menduduki urutan pertama di Asia dengan penderita stroke terbanyak dan menjadi penyakit penyebab kematian tertinggi di Indonesia (Yastroki, 2012). Berdasarkan data hasil Riset Kesehatan Dasar (Riskesdas) tahun 2013 menunjukkan hasil prevalensi stroke terlihat meningkat seiring peningkatan umur responden. Prevalensi stroke sama banyaknya pada laki-laki dan perempuan. Prevalensi stroke di Indonesia telah terdiagnosis oleh tenaga kesehatan sebanyak 57,9\% (Riskesdas, 2013). Berdasarkan data rekam medis RSUD A. Wahab Sjahranie Samarinda, jumlah pasien stroke yang dirawat dari bulan Januari Desember 2014 berjumlah 1.195 orang dengan rata-rata tingkat kemandirian pasien stroke yang dirawat masuk dalam kategori partly sampai wholly compensatori dalam hal pemenuhan bantuan aktivitas (Rekam medis RSUD A. Wahab Sjahranie Samarinda, 2014). Stroke merupakan penyebab utama dari kecacatan pada orang dewasa dan merupakan diagnosis utama teratas dalam perawatan jangka panjang. Lebih dari empat juta penderita stroke yang bertahan hidup dengan tingkat kecacatan yang bervariasi di Amerika Serikat. Sejalan dengan tingginya tingkat kematian pada stroke, penyakit ini juga menyebabkan angka kesakitan atau morbiditas yang signifikan pada orang-orang yang bisa bertahan dengan penyakit stroke (Black \& Hawks, 2014). Keparahan paresis paska stroke merupakan salah satu hal yang dipertimbangkan memiliki kaitan dengan kapabilitas fungsional, pemulangan dan mortalitas (Glinsky, Harvey \& Es, 2007). Stroke secara jelas dapat berdampak pada disfungsi ekstremitas yang merupakan gangguan fungsional yang paling umum terjadi yaitu sebanyak $88 \%$ penderita stroke berupa kehilangan kontrol ekstremitas yang dapat menurunkan kekuatan otot yang akan berdampak pada penurunan kemampuan Activities of daily living (ADL). Beberapa terapi yang telah dilakukan untuk mengatasi kelemahan otot dan keterbatasan ADL seperti latihan rentang gerak, pemberian posisi, dan akupresur merupakan salah satu bentuk terapi yang dapat dilakukan untuk mengembalikan fungsi ekstremitas. Akupresur merupakan suatu metode 
pengobatan dengan memberikan penekanan pada titik meridian pada aliran $q i$ tubuh (energi vital dan merupakan unsur dasar dari seluruh bentuk pergerakan dan perubahan seluruh fenomena di alam semesta). Dengan memperbaiki aliran qi, fungsi ekstremitas dan kemampuan melakukan aktivitas seharihari pada pasien paska stroke dapat membaik.

\section{METODE PENELITIAN}

Penelitian ini merupakan penelitian kuantitatif, menggunakan metoda quasi eksperiment dengan pendekatan pretest, posttest wih control group design untuk mengetahui pengaruh akupresur terhadap kekuatan otot dan Activities of daily living (ADL). Pada desain ini terdapat dua kelompok yaitu kelompok intervensi yang akan diberikan tindakan akupresur dan kelompok kontrol yang mendapatkan perawatan rutin. Kelompok intervensi diberi perlakuan perawatan rutin dan akupresur dan kelompok kontrol hanya diberi perlakuan perawatan rutin. Peneliti melakukan analisis uji pengaruh, uji beda berpasangan dan uji beda independen untuk mengidentifikasi pengaruh akupresur terhadap kekuatan otot dan kemampuan ADL pada pasien stroke yang dirawat di RSUD A.Wahab Sjahranie Samarinda.

\section{HASIL}

Data diolah dengan uji univariat, bivariat, dan multivariat.

\section{1) Analisis Univariat}

\section{Tabel 1}

Distribusi Karakteristik Responden

\begin{tabular}{rlcc}
\hline No & Karakteristik & $\mathrm{n}$ & $\%$ \\
\hline 1 & Usia & & \\
& $45-59$ th & 66 & $(58,4)$ \\
& $60-74$ th & 39 & $(34,5)$ \\
& $75-90$ th & 7 & $(6,2)$ \\
& $>90$ & 1 & $(9)$
\end{tabular}

2 Jenis kelamin

\begin{tabular}{|c|c|c|}
\hline Laki-laki & 58 & (51.3) \\
\hline Perempuan & 55 & $(48.7)$ \\
\hline $\begin{array}{l}\text { Frekuensi stroke } \\
\text { Serangan ke- } 2 \text { dst }\end{array}$ & 17 & $(-15)$ \\
\hline Serangan pertama & 96 & $(-85)$ \\
\hline Kekuatan otot kanan & & \\
\hline 1 & 1 & $(0,9)$ \\
\hline 2 & 10 & $(8,8)$ \\
\hline 3 & 35 & $(31)$ \\
\hline 4 & 20 & $(17,7)$ \\
\hline 5 & 47 & $(41,6)$ \\
\hline
\end{tabular}

5 Kekuatan otot kiri

0
$(8)$
$18,6)$
$(15)$
$58,4)$
0
$30,1)$
$69,9)$
0

Berdasarkan tabel 1 diketahui bahwa karakteristik responden dalam penelitian ini adalah $66(58,4 \%)$ responden dalam rentang usia 45-59 tahun, $58(51,3 \%)$ responden berjenis kelamin laki-laki, dan sebanyak 96 (85\%) responden mengalami serangan stroke untuk yang pertama kali, kekuatan otot kanan dengan nilai 3 sebanyak 35 responden (31\%) dari 66 responden, kekuatan otot kiri dengan nilai 3 sebanyak 21 responden $(18,6 \%)$ dari 47 responden dan kemampuan ADL dalam rentang ketergantungan berat (>20 - <40) sebanyak 79 responden $(69,9 \%)$ dari 113 responden.

2) Analisis Bivariat

\section{Tabel 2.}

Hasil Uji Beda Sebelum dan Sesudah Intervensi

\begin{tabular}{rlc}
\hline No & \multicolumn{1}{c}{ Variabel } & pvalue \\
\hline 1 & Kekuatan otot kanan & 0.000 \\
2 & Kekuatan otot kiri & 0.000 \\
3 & ADL & 0.000 \\
\hline
\end{tabular}


Berdasarkan Tabel 2, didapatkan nilai p < 0.005 pada ketiga variabel. Ini menunjukkan bahwa secara statistik ada peningkatan kekuatan otot kiri dan kanan dan ADL yang signifikan sebelum intervensi dengan sesudah intervensi.

3) Analisis Multivariat

Tabel 3

Uji Pseudo R-Square Antar Kelompok Intervensi

\begin{tabular}{lc}
\hline \multicolumn{1}{c}{ Variabel Dependen } & Cox and Snell \\
\hline Kekuatan otot kanan & 0,276 \\
Kekuatan otot kiri & 0,158 \\
ADL & 0,451 \\
\hline \multicolumn{2}{c}{ Berdasarkan } \\
\hline
\end{tabular}

kontribusi variabel independen terhadap variabel dependen dijelaskan sebagai berikut:

1. Pada variabel kekuatan otot kanan didapatkan nilai Cox and Snell sebesar 0,276, secara statistik disimpulkan bahwa variabel independen (akupresur, usia, jenis kelamin dan frekuensi stroke) memberikan kontribusi terhadap variabel dependen sebesar 27,6\%, sisanya $72,4 \%$ dijelaskan oleh variabel di luar model atau variabel yang tidak diteliti.

2. Pada variabel kekuatan otot kiri didapatkan nilai Cox and Snell sebesar 0,158, secara statistik disimpulkan bahwa variabel independen (akupresur, usia, jenis kelamin dan frekuensi stroke) memberikan kontribusi terhadap variabel dependen sebesar 15,8\%, sisanya $84,2 \%$ dijelaskan oleh variabel di luar model atau variabel yang tidak diteliti.

3. Pada variabel ADL didapatkan nilai Cox and Snell sebesar 0,451, secara statistik disimpulkan bahwa variabel independen (akupresur, usia, jenis kelamin dan frekuensi stroke) memberikan kontribusi terhadap variabel dependen sebesar 45,1\%, sisanya $54,9 \%$ dijelaskan oleh variabel di luar model atau variabel yang tidak diteliti.

\section{Tabel 4}

Uji Parameters Estimates pada kekuatan otot kanan

\begin{tabular}{lcc}
\hline \multicolumn{1}{c}{ Variabel } & \multicolumn{2}{c}{ Hasil Parameters } \\
\cline { 2 - 3 } Indeptimatenden \\
\cline { 2 - 3 } Koefisien 2 & Estimate & Nilai p \\
Koefisien 3 & $-7,078$ & 0,001 \\
Koefisien 4 & $-5,117$ & 0,006 \\
Intervensi & $-3,152$ & 0,070 \\
Jenis kelamin & $\mathbf{2 , 3 8 0}$ & $\mathbf{0 , 0 0 2}$ \\
Usia & $-0,205$ & 0,778 \\
Frekuensi & $\mathbf{- 1 , 9 3 3}$ & $\mathbf{0 , 0 0 0}$ \\
stroke & 1,431 & 0,067 \\
\hline
\end{tabular}

Berdasarkan Tabel 4, pengaruh

variabel independen terhadap variabel dependen kekuatan otot kanan didapatkan nilai $\mathrm{p}=0,002$ pada variabel intervensi dan nilai $\mathrm{p}=0,000$ pada variabel usia $(\mathrm{p}=<0,05)$, sedangkan variabel jenis kelamin dan frekuensi stroke nilai $\mathrm{p}=>0,05$. Secara statistik disimpulkan bahwa akupresur dan usia secara signifikan mempengaruhi peningkatan kekuatan otot ekstremitas kanan pada pasien stroke, sementara jenis kelamin dan frekuensi stroke tidak memberikan pengaruh signifikan terhadap peningkatan kekuatan otot ekstremitas kanan pasien stroke yang diberikan intervensi akupresur.

\section{Tabel 5}

\section{Uji Parameters Estimates pada} kekuatan otot kiri

\begin{tabular}{lcc}
\hline \multicolumn{1}{c}{ Variabel } & \multicolumn{2}{c}{ Hasil Parameters Estimates } \\
\cline { 2 - 3 } \multicolumn{1}{c}{ Dependen } & Estimate & Nilai p \\
\hline Koefisien 3 & $-7,021$ & 0,010 \\
Koefisien 4 & $-5,743$ & 0,029 \\
Intervensi & $\mathbf{1 , 8 7 5}$ & $\mathbf{0 , 0 3 9}$ \\
Jenis kelamin & $-2,229$ & 0,061 \\
Usia & $-0,906$ & 0,113 \\
Frekuensi stroke & 1,566 & 0,094 \\
\hline
\end{tabular}


Berdasarkan Tabel 5, pengaruh variabel independen terhadap variabel dependen kekuatan otot kiri didapatkan nilai $\mathrm{p}=0,039(\mathrm{p}=<0,05)$ pada variabel intervensi. Pada variabel jenis kelamin, usia dan frekuensi stroke nilai $\mathrm{p}=>0,05$. Secara statistik disimpulkan bahwa hanya akupresur yang memberikan pengaruh secara signifikan terhadap peningkatan kekuatan otot ekstremitas kiri pada pasien stroke, sementara jenis kelamin, usia dan frekuensi stroke tidak memberikan pengaruh signifikan terhadap peningkatan kekuatan otot ekstremitas kiri pasien stroke yang diberikan intervensi akupresur.

Tabel 6

Uji Parameters Estimates pada ADL

\begin{tabular}{lcc}
\hline \multirow{2}{*}{$\begin{array}{c}\text { Variabel } \\
\text { Dependen }\end{array}$} & \multicolumn{2}{c}{$\begin{array}{c}\text { Hasil Parameters } \\
\text { Estimates }\end{array}$} \\
\cline { 2 - 3 } & Estimate & Nilai p \\
\hline Koefisien 1 & 4,150 & 0,028 \\
Koefisien 2 & 6,830 & 0,001 \\
Intervensi & $\mathbf{- 3 , 3 0 6}$ & $\mathbf{0 , 0 0 0}$ \\
Jenis kelamin & 1,072 & 0,160 \\
Usia & $\mathbf{2 , 6 6 6}$ & $\mathbf{0 , 0 0 0}$ \\
Frekuensi stroke & $\mathbf{- 2 , 1 6 7}$ & $\mathbf{0 , 0 0 7}$ \\
\hline
\end{tabular}

Berdasarkan Tabel 6 pengaruh variabel independen terhadap variabel dependen $\mathrm{ADL}$ didapatkan nilai $\mathrm{p}=$ $0,000 \quad(\mathrm{p}=<0,05)$ pada variabel intervensi, nilai $\mathrm{p}=0,000(\mathrm{p}=<0,05)$ pada variabel usia dan nilai $\mathrm{P}=0,007(\mathrm{p}$ $=<0,05)$, pada variabel frekuensi stroke, sedangkan variabel jenis kelamin nilai $\mathrm{p}=>0,05$. Secara statistik disimpulkan bahwa akupresur, usia dan frekuensi stroke secara signifikan mempengaruhi peningkatan ADL pada pasien stroke, sementara jenis kelamin tidak memberikan pengaruh signifikan terhadap peningkatan ADL pasien stroke yang diberikan intervensi akupresur.
Tabel 7

Uji Parallel Lines

\begin{tabular}{lcc}
\hline \multicolumn{1}{c}{$\begin{array}{c}\text { Variabel } \\
\text { Independen }\end{array}$} & Peringkat & Nilai p \\
\hline Kekuatan otot kanan & II & 0,000 \\
Kekuatan otot kiri & III & 0,000 \\
ADL & I & 0,162 \\
\hline
\end{tabular}

Berdasarkan table 7, besarnya pengaruh variabel independen (akupresur, usia, jenis kelamin, dan frekuensi stroke) secara simultan terhadap variabel dependen (kekuatan otot ekstremitas kanan dan kiri dan ADL) didapatkan nilai $p$ tertinggi adalah ADL. Secara statistik disimpulkan bahwa akupresur, usia, jenis kelamin, dan frekuensi stroke secara simultan paling besar mempengaruhi peningkatan ADL pasien stroke yang diberikan intervensi akupresur.

\section{PEMBAHASAN}

\section{Pengaruh Akupresur Terhadap Kekuatan Otot dan ADL}

Pengaruh akupresur terhadap peningkatan kekuatan otot dan Activities $O f$ Daily Living (ADL) dianalisis berdasarkan uji regresi logistic ordinal. Hasil uji regresi logistic ordinal secara statistic menunjukkan bahwa intervensi akupresur mempengaruhi kekuatan otot dan ADL secara bermakna. Pengaruh akupresur terhadap kekuatan otot ditunjukkan dengan nilai parameter estimate 2,380 untuk kekuatan otot kanan dengan nilai $\mathrm{p}=0,002(<0,05)$ dan odds rasio 16,86 . Nilai parameter estimate untuk kekuatan otot kiri adalah 1,875 dengan nilai $\mathrm{p}=0,039$ $(<0,05)$ dan odds rasio 6,5. Pengaruh akupresur terhadap ADL ditunjukkan dengan nilai parameter estimate $-3,303$ 
dengan nilai $\mathrm{p}=0,000(<0,05)$ dan odds rasio 4,2.

Peningkatan kekuatan otot terlihat pada nilai kekuatan otot responden yang diukur menggunakan skala Medical Research Council Scale. Pada awal pengukuran, sebelum dilakukan intervensi akupresur, mayoritas responden memiliki tingkat kekuatan otot 3 yaitu sebanyak 56 responden dari 113 responden, 37 responden memiliki tingkat kekuatan otot 3 dan 1 responden memiliki nilai kekuatan otot 1 . Setelah dilakukan intervensi akupresur selama 7 hari pada masing-masing responden, tingkat kekuatan otot meningkat yaitu sebanyak 91 responden memiliki nilai kekuatan otot 5 (normal) dan tidak ada responden yang memiliki tingkat kekuatan otot 1 .

Pengaruh akupresur terhadap peningkatan kemampuan ADL diukur dengan menggunakan Barthel index. Sebelum intervensi akupresur, mayoritas responden memiliki tingkat kemampuan ADL 3 (tingkat ketergantungan berat) yaitu sebanyak 79 responden dari 113 responden dan tidak ada responden yang memiliki tingkat kemampuan ADL 1 (mandiri). Setelah dilakukan akupresur, tingkat kemampuan ADL responden meningkat yaitu sebanyak 93 responden memiliki tingkat kemampuan ADL mandiri.

Peningkatan kekuatan otot dan kemampuan ADL setelah diberikan intervensi akupresur terlihat dari kemampuan responden dalam keterlibatan klien dalam aktivitas pemenuhan kebutuhan dasar contohnya dalam kemampuan berpakaian, setelah intervensi klien dapat berpakaian sendiri dengan bantuan minimal dari orang lain, dalam kemampuan toileting beberapa klien dapat melakukannya di kamar mandi dengan bantuan minimal tanpa bantuan alat dimana sebelum intervensi klien mengeluh sangat sulit berpindah tempat, menggerakkan tangan dan kaki saja terasa berat. Temuan ini sejalan dengan hasil penelitian sebelumnya yang dilakukan oleh Kang \& Soek (2009) pada 56 pasien pasca stroke di Korea. Pada kelompok intervensi yang dilakukan akupresur terjadi peningkatan rentang gerak dimana hasil penelitian ini mendukung pemberian akupresur dimana penekanan pada titik meridian dapat memperbaiki aliran $q i$ dan darah dalam tubuh sehingga dapat merelaksasi otot tubuh dan merangsang perbaikan alamiah pada abnormalitas skeletal dan kemampuan gerak meningkat. Selain itu pemberian terapi akupresur akan mengharmonisasikan aliran $q i$ dan darah sehingga merelaksasikan spasme dan meredakan nyeri pada sendi karena menstimulasi pelepasan endorphine.

Peningkatan kekuatan otot pasien mempengaruhi peningkatan kemampuan ADL klien. Orem menekankan bahwa kebutuhan self-care individu dapat dipenuhi oleh perawat, individu atau keduanya. Sistim keperawatan dirancang oleh perawat berdasarkan kebutuhan self-care dan kemampuan individu dalam memenuhi 'selfcare'nya. Keperawatan mengambil peran penting dalam membantu individu yang mengalami defisit/penurunan kemampuan dalam perawatan diri. Perawat berperan meningkatkan kemampuan pasien stroke dalam pemenuhan kebutuhan perawatan diri. Perawatan diri pasien bukan hanya menjadi tanggung jawab perawat, tetapi juga menjadi tanggung jawab pasien. Perawat berperan sebagai fasilitator dalam memandirikan pasien stroke yang mengalami defisit perawatan diri supaya pasien dapat 
menggunakan dirinya seoptimal mungkin dalam usaha perawatan dirinya. Hasil akhir dari teori Orem adalah kemandirian pasien dalam perawatan dirinya. Pada tahap awal, perawat lebih mengambil peran, tetapi semakin lama perawat akan memandirikan pasien sehingga peran perawat menjadi minimal dan peran pasien menjadi lebih dominan. Teori self-care dari Orem sesuai untuk diaplikasikan pada rehabilitasi pasien pasca stroke.

Hal ini ditegaskan oleh McEwen (2007) bahwa teori self-care dari Orem direkomendasikan pada layanan program rehabilitasi individu dengan penurunan kekuatan dan fungsi fisik. Tujuan aplikasi teori ini adalah meningkatkan kemandirian dan kualitas hidup individu, peran perawat adalah mengompensasi keterbatasan aktivitas pasien dan mengoptimalkan kemandirian yang masih dimiliki pasien.

\section{Pengaruh Variabel Independen Secara Parsial}

Berdasarkan hasil uji regresi, didapatkan nilai $\mathrm{p}=0,000$ pada variabel usia. Secara statistik disimpulkan bahwa ada pengaruh yang signifikan antara usia terhadap kekuatan otot dan ADL. Usia merupakan faktor resiko yang tidak dapat dimodifikasi namun merupakan faktor resiko yang penting untuk terjadinya stroke. Dilaporkan bahwa stroke iskemik yang menginjak usia lansia akan mengalami keterbatasan fungsional yang lebih parah dibandingkan dengan pasien stroke yang lebih muda (AHA, 2010).

Pada penelitian ini, mayoritas usia responden berada pada usia pertengahan (middle age) sehingga tujuan penelitian yaitu peningkatan kekuatan otot dan kemampuan ADL dapat dicapai. Hal ini sesuai dengan pernyataan American Stroke
Association (2012) yang menyatakan bahwa pasien yang mengalami serangan stroke pada usia tua akan mengalami keterbatasan fungsional lebih parah dan membutuhkan waktu lebih lama untuk perbaikan fungsi dibandingkan pada usia pertengahan. Proses penuaan dikaitkan dengan resiko yang lebih besar terhadap kematian sel. Penurunan mitosis menyebabkan kecepatan jumlah sel yang rusak tidak seimbang dengan jumlah sel yang baru. Keadaan ini menyebabkan tubuh lebih banyak kehilangan sel, daripada jumlah sel yang baru sebagai pengganti. Kehilangan sel-sel tubuh, menyebabkan penurunan kekuatan dan efisiensi fungsi tubuh, terkait dengan perubahan otot (Hurlock, 2011).

Berdasarkan hasil uji regresi pada variabel jenis kelamin didapatkan nilai $\mathrm{p}=$ 0,778 pada kekuatan otot kanan, $\mathrm{p}=0,061$, dan $\mathrm{p}=0,160$ pada ADL. Secara statistik disimpulkan bahwa tidak ada pengaruh yang signifikan antara jenis kelamin terhadap kekuatan otot dan ADL. Hasil penelitian ini kurang sesuai dengan jurnal Cerebral Ischemic Stroke: is Gender Important (3013) yang menyatakan bahwa pemulihan pasca stroke dipengaruhi jenis kelamin dimana laki-laki dan perempuan memiliki anti koagulan yang sama namun pada perempuan memiliki 0,2 resiko lebih tinggi mengalami stroke iskemik daripada lakilaki. Hal ini mempengaruhi respon terhadap terapi pasca stroke dimana perempuan memiliki hasil fungsional yang lebih buruk dibandingkan laki-laki. Penelitian yang dilakukan CL Gibson (2013) juga menemukan bahwa wanita memiliki tingkat pemulihan pasca stroke yang buruk dibandngkan laki-laki. Perempuan memiliki kecenderungan mengalami keterbatasan fisik berupa kelemahan dan rentang gerak 
yang lebih parah dibandingkan dengan lakilaki dan menunjukkan tingkat pemulihan yang lebih rendah dibandingkan laki-laki. Turzo \& McCullough (2008) mendukung pernyataan ini dengan mengemukakan bahwa jenis kelamin perempuan lebih banyak mengalami tingkat pemulihan yang lebih rendah setelah terserang stroke yaitu hanya sekitar $22,7 \%$ perempuan yang pulih total dalam 6 bulan dibandingkan dengan laki-laki yang dapat pulih secara total sebanyak 26,7\% dalam 6 bulan sejak serangan stroke.

Berdasarkan hasil uji regresi pada variabel frekuensi stroke di didapatkan nilai $\mathrm{p}=0,067$ pada kekuatan otot kanan, $\mathrm{p}=0,094$ pada kekuatan otot kiri dan $\mathrm{p}=0,007$ pada ADL. Secara statistik disimpulkan bahwa ada pengaruh yang signifikan antara frekuensi stroke terhadap ADL. Pasien dengan serangan stroke yang berulang menandakan adanya kerusakan system neurologis yang lebih luas dibandingkan dengan orang yang baru terserang stroke yang pertama. Pada saat pemulihan orang dengan serangan stroke berulang membutuhkan waktu dan latihan yang lebih lama (AHA, 2007).

\section{Pengaruh Intervensi dan Karakteristik Responden Secara Simultan}

Pengaruh intervensi akupresur, usia, jenis kelamin, frekuensi stroke secara simultan terhadap kekuatan otot dan ADL dapat diketahui dari hasil Pseudo R-Squarr dengan melihat nilai Cox and Snell pada uji regresi logistik ordinal. Hasil uji regresi logistik ordinal pada variabel kekuatan otot kanan secara statistik menunjukkan bahwa akupresur, usia, jenis kelamindan frekuensi stroke mempunyai pengaruh terhadap kekuatan otot kanan sebesar 27,6\% sedangkan sisanya $(72,4 \%)$ dijelaskan oleh variabel di luar model atau variabel yang tidak diteliti. Pada variabel kekuatan otot kiri secara statistik menunjukkan bahwa akupresur, usia, jenis kelamin dan frekuensi stroke mempunyai pengaruh 15,8\% sedangkan sisanya $(84,2 \%)$ dijelaskan oleh variabel di luar model atau variabel yang tidak diteliti. Pada variabel ADL secara statistik menunjukkan bahwa akupresur, usia, jenis kelamin, dan frekuensi stroke mempunyai pengaruh 45,1 \% sedangkan sisanya $(54,9 \%)$ dijelaskan oleh variabel yang tidak diteliti .Berdasarkan nilai Cox and Snell tersebut diketahui bahwa masih terdapat lebih dari $60 \%$ faktor predictor lain yang mempengaruhi kekuatan otot dan ADL pasien stroke. Peneliti menganalisis beberapa faktor yang tidak diteliti namun mempengaruhi kekuatan otot dan ADL pasien stroke antara lain tipe stroke dan Admission time.

Tipe atau jenis stroke merupakan faktor predictor yang mempengaruhi tingkat pemulihan pasca stroke yaitu peningkatan kekuatan otot dan ADL. Stroke nonhemoragik memiliki tingkat pemulihan yang lebih cepat jika dibandingkan dengan stroke hemoragik. Dilihat dari insiden bahwa stroke nonhemoragik lebih tinggi dari pada stroke hemoragik, namun tingkat mortalitas lebih banyak pada stroke hemoragik (AHA, 2007). Hemiparese terjadi sebanyak $74 \%$ setelah mengalami stroke iskemik dan hanya $26 \%$ setelah mengalami stroke hemoragik. Lebih lanjut, penelitian Siddique et al (2009) menunjukkan bahwa hemiparese terjadi lebih banyak pada pasien dengan stroke iskemik dibandingkan dengan stroke hemoragik. Pasien dengan stroke iskemik mengalami hemiparese sebanyak $64,8 \%$ sedangkan pasien dengan stroke 
hemoragik mengalami hemiparese hanya $17,85 \%$.

Berdasarkan uji statistik dapat disimpulkan bahwa akupresur memberikan pengaruh terhadap peningkatan kekuatan otot dan kemampuan ADL pasien stroke setelah diberikan intervensi. Peningkatan kemampuan terlihat dari keterlibatan klien dalam aktivitas pemenuhan kebutuhan dasar contohnya dalam kemampuan berpakaian, setelah intervensi klien dapat berpakaian sendiri dengan bantuan minimal dari orang lain, dalam kemampuan toileting beberapa klien dapat melakukannya di kamar mandi dengan bantuan minimal tanpa bantuan alat dimana sebelum intervensi klien mengeluh sangat sulit berpindah tempat, menggerakkan tangan dan kaki saja terasa berat.

\section{SIMPULAN}

Berdasarkan uji statistik diketahui bahwa ada perbedaan kekuatan otot dan ADL yang bermakna setelah dilakukan akupresur selama 7 hari pada masing-masing responden dengan nilai $\mathrm{p}=0,000$ (nilai $\mathrm{p}<0,05)$ dan peningkatan kekuatan otot dan kemampuan ADL dipengaruhi oleh usia $(p=0,000)$ dan frekuensi stroke $(p=0,007)$.

\section{REFERENSI}

Alamsyah (2010). Cara lebih mudah menemukan titik terapi acupoint, Petunjuk praktis akupunktur. Jakarta : AsmaNadia Publishing House.

Alternative Medicine Info. (2009). Acupressure. February 2, 2015. http://www. about-acupressure.com/ acupressure/description

American Heart Association. (2010). Heart disease and stroke statistic - 2010 update. Dallas Texas : American Heart Association.

American Heart Association. (2007a). Let's talk about complication after stroke. Mei

2 ,

2011. http://www.strokeassociation.org/idc/g roups/stroke

American Heart Association. (2007b). Heart disease and stroke statistic - 2008 update: A report from the american heart association statistic committee and stroke statistic subcommitte. Circulation: Journal of the American Heart Association, 117(4), e25-146.

Bernhard, J., Chan, J., Nicola I, \& Collier, J. M. (2007). Little therapy, little physical activity: Rehabilitation within the first 14 day of organized stroke unit care. J Rehabil Med, 39, 43-48.

Bhakta, B. B., Cozens, A. J., Chamberlain, M.A., \& Bamford, J. M. (2000). Impact of botulinum toxin type $A$ on disability and career burden due to arm spasticity after stroke: A randomized double blind controlled trial. J Neurol Neurosurg Psychiatry, 69, 217-221

Black, J. M., \& Hawk, J. H. (2014). Medical surgical nursing: clinical management for positive outcomes (Vol 2, 8th Ed.). St.Louis, Missouri: Saunders Elsevier.

Borisova, Y. \& Bohannon, R. W. (2009). Positioning to prevent or reduce shoulder range of motion impairments after stroke: A meta-analysis. Clinical Rehabilitation, 23(8), 681-690.

Braun, M. B., \& Smonson, S. (2008). Introduction to massage therapy (2nd Ed.). Philadephia: Lippincott Williams \& Wilkins.

Dromerick, A. W., Catherine, E. L., Birkenmeier, R., Hahn, M. G., MS, Sahrmann, S. A., Edwards, D. F. (2006). Relationships between upperlimb functional limitation and selfreported disability 3 months after stroke. Journal of Rehabilitation Research and Development, 43, 3, 401-408.

Dupler, Douglas. (2005). Gale Encyclopedia of Alternative Medicine. Acupressure. http://www.encyclopedia.com/topic/A cupressure.aspx. February 15, 2011. East-West Nursing Research Institute. (2001). East-west nursing mediation. Seoul: Hyun Moon Sa.

Ginsberg, L. (2008). Lecture notes: Neurologi (Indah R Wardhani, Penerjemah). Jakarta: Penerbit Erlangga.

Chang KK et al. (20110. Effect of Acupressure in Treating Urodynamic Stress Incontinence: A Randomized 
Controled Trial. Am J Chin Med 2011;39;1139-1159

Christensen, P. J., \& Kenney, J. W. (2009). Proses keperawatan, Aplikasi model konseptual (Terj. dari Nursing process: Application of conceptual models. (4th Ed.). Jakarta: Penerbit Buku Kedokteran EGC.

Christenseen, B., \& Kockrow, E (2005). Acute coronary syndrome and stroke. St. Louis, Missouri: Mosby Elsevier.

Claire L. Gibson. (2013). Cerebral Iscemic Stroke: is Gender Important?. Journal of Cerebral Blood Flow \& Metabolism

Current Nursing (2011). Nursing Theories, Martha Roger's Science of Unitary Human Beings. Febriary 1, 2015. http://currentnursing.com/nursing theory/unitary_human_beings.html

Dahlan, M. Sopiyodin. (2008). Seri Evidence based medicine, Langkahlangkah membuat proposal penelitian bidang kedokteran dan kesehatan. Jakarta: CV. Sagung Seto.

Damush, T. M., Plue, L., Bakas, T., Schmid, A., \& Williams, L. S. (2007). Barriers and facilitators to exercise among stroke survivors. Rehabilitation Nursing, 32(6), 253-60, 262.

Glinsky, J., Harvey, L. \& Es, P. V. (2007). Efficacy of electrical stimulation to increase muscle strength in people with neurological conditions: A systematic review. Physiotherapy Research International, 12 (3), 175194.

Hamilton Nancy \& Lutlgens Kathryn. (2012). musculoskeletal system. (Vol. 6, 7th Ed). St.Louis: Mosby Elsevier.

Heart Disease and Stroke Statistic (2006). Update: A report from the american Heart association statistic committee and stroke statistic committe. Circulation: Journal of the American Heart Association, 113, $85-115$.

Hill, M. D. \& Buchan, A. M. (2005). Thrombolysis for acute ischemic stroke: Results of the Canadian alteplase for stroke effectiveness study. Canadian alteplase for stroke effectiveness study (CASES) investigators. CMAJ, 172:1307.

Ira Trionggo \& Abdul Ghofar. (2013). Panduan Sehat Sembuhkan Penyakit dengan Pijat dan Herbal. Yogyakarta: Indoliterasi.
Institute of Health Metrics and Evaluation. (2013). Asian population life expectancy. Havard University.

Joanne, M. W., Catherine, E. L., Shirley, A. S., Dorothy, F. E., Alexander, W. D. (2007). Sensorimotor impairments and reaching performance in subjects with poststroke hemiparesis during the first few months of recovery. Physical Therapy, 87,6, 751-765.

J. Wasay. (2014). Epidemoligy of stroke: hypertension, lifestyle and Fast food. St. Louis, Missouri: Mosby, Elsevier.

Kang, H. S., Sok, S. R., Kang, J. S. (2009). Effects of meridian acupressure for stroke patient in Korea. Journal of Clinical Nursing, 18, 2145-2151.

Lee JS. (2011). Acupressure for Treating Neurological Disorder. South Korea: Kyung He University.

Lewis, S. L., Heitkemper, M. M., Bucher, L., et al. (2007). Medical surgical nursing: Assesment and management of clinical Problems (Vol. 2, 7th Ed). St.Louis: Mosby Elsevier.

Narendra, Fagun, Bhatt. (2013). A Comparative Study of Effectiveness of Balance Training with and Without Visual Cues on Activities of Daily Living in Stroke Patients. India: Institute of Medical Sciences.

National Stroke Foundation (2009). National stroke audit acute services organizational survey report 2009.

North American Nursing Diagnosis Association. (2009). Nursing diagnoses: definitions and classification. USA: Jhon Wiley \& Sons Inc.

Patrea Putranto, Yulieta Sihombing. (2009). Hubungan Umur, jenis kelamin dan hipertensi dengan kejadian stroke. Jakarta.

Polit, D. F., \& Hungler, B. P. (2004). Nursing research : principles and methods (6th Ed.). Philadelphia: Lipincott Williams \& Wilkins.

Salisbury, Meredith M. (2011). Stroke in Young. Candidian Journal of Neurological Sciences, 38 (3) 404410.

Shin, B. C. \& Lee, M. S. (2007). Effects of aromatherapy acupressure on hemiplegic shoulder pain and motor power in stroke patients: A pilot study. The Journal of Alternative And 
Complementary Medicine, 13 (2), 247-251.

Susilo Putro. (2014). Akupressure dan Reflexologi. Yayasan Wanita Katolik RI, Jakarta.

Tomey \& Alligood. (2006). Nursing theorists and their work (6th Ed.). St. Louis, Missouri: Mosby, Elsevier.

$\mathrm{Wu}$ et al. (2010). Responsiveness and Validity of Two Outcome Measures of Instrumental Activities od Daily Living in Stroke. Taiwan: Taiwan University.

Yayasan Stroke Indonesia (Yastroki).

(2010). Golden period/periode emas. February 28, 2015. http://www.cegahstroke.com/goldenperiod.php 